\title{
Penyesuaian Masalah Agensi (Agency Problem) dalam Kontrak Pembiayaan Mudharabah
}

\author{
Muhammad \\ Dosen Sekolah Tinggi Ekonomi Islam Yogyakarta
}

\begin{abstract}
ABSTRAK
Kontrak mudharabah merupakan salah satu bentuk mekanisme keuangan syari'ah yang digunakan untuk menggantikan sistem bunga. Dalam kontrak ini terdapat hubungan antara pemilik modal (shahibul mal/principal) dengan pelaku usaha (mudharib/agents). Kontrak mudharabah adalah kontrak menanggung untung dan rugi antara pemilik dana (bank/principals) dengan nasabah (agents). Hubungan kontrak keuangan seperti dalam mudharabah ini biasanya dikenal dengan nama hubungan agency (agency contractual). Oleh karena itu, kontrak seperti ini menuntut adanya transparansi bagi pihak pelaku usaha. Jika salah satu pihak (utamanya nasabah) tidak menyampaikan secara transparan tentang hal-hal yang berhubungan dengan perolehan hasil, sehingga dapat terjadi aktivitas adverse selection dan moral hazard. Dalam transaksi keuangan, masalah adverse selection dan moral hazard merupakan masalah asymmetric information. Kontrak mudharabah adalah kontrak keuangan yang sarat dengan aktivitas asymmetric information.
\end{abstract}

Keywords: Agency problems; Asymmetric information; Shahibul mal; Mudharib

Salah satu bentuk kontrak keuangan atau pembiayaan yang dikembangkan untuk menggantikan mekanisme bunga dalam kontrak keuangan atau pembiayaan konvensional adalah kontrak mudharabah (Murinde, Naser dan Wallace, 1995). Bentuk-bentuk ini, didasarkan pada relasi profit and loss sharing antara pemberi dana (shahibul mal) dan pengusaha (mudharib) yang menggunakan dana tersebut untuk diinvestasikan dalam berbagai proyek. Dalam berbagai konteks tertentu, profit and loss sharing diinterpretasikan sebagai bentuk pembiayaan modal dimana return-nya tidak ditentukan ataupun dijamin akan didapat di muka. Kontrak mudharabah ini memiliki peran utama dalam sistem perbankan syari'ah dalam mendistribusikan return pada suatu investasi tanpa menggunakan bunga.

Kontrak mudharabah dapat digambarkan sebagai suatu relasi kontraktual antara dua pihak, yang diatur oleh syariah, untuk menggabungkan (tenaga) manusia dan modal dana untuk melaksanakan suatu proyek investasi kerjasama yang beresiko tetapi menguntungkan. Pihak pertama adalah pemberi dana (rabbul maal/shahibul al-maal) yang menyediakan dana yang dibutuhkan dalam pendirian suatu usaha, bisnis atau jasa yang bertujuan untuk menghasilkan keuntungan. Pihak kedua adalah pengusaha (mudharib) menyediakan modal 
(tenaga) manusia dan berperan sebagai yang menjalankan usaha. Pengusaha juga bertugas untuk menjalankan hak kontrol atas investasi tersebut. Return positif dari kontrak tersebut menghasilkan keuntungan yang kemudian dibagikan kepada kedua belah pihak berdasarkan kesepakatan nisbah yang telah ditentukan di muka. Hasil negatif (kerugian) yang terjadi dalam proses aktivitas (usaha) yang terjadi secara alamiah ditanggung oleh pemberi dana sebagai pihak tunggal penyedia dana. Kerugian akan ditanggung oleh pengusaha jika mengalami kegagalan dalam menjalankan proyek tersebut adalah berupa tenaga dan waktu yang telah dicurahkan. Jadi kontrak mudharabah merefleksikan inti dari politik ekonomi Islam, dimana dalam sistem ekonomi Islam, pembagian resiko (kerugian dan keuntungan) merupakan aksioma yang fundamental.

Dalam wacana keuangan konvensional, hubungan kontrak keuangan seperti dalam mudharabah ini biasanya dikenal dengan nama hubungan agency (agency contractual). Akan tetapi dalam kerangka teori agensi, kontrak risk and profit sharing yang ideal berkaitan dengan kedua belah pihak, yang memiliki kemungkinan kepercayaan yang identik dengan penghormatan kepada bentuk asal. Pihak yang satu merupakan the insider (yang aktif) yang diidentifikasi sebagai agen (pengusaha). Agen memiliki pengetahuan mengenai proyek investasi yang beresiko tetapi menguntungkan. Agen berharap untuk terjun di dalamnya, tetapi dia tidak memiliki dana awal untuk membiayai proyek tersebut. Pihak the outsider (yang pasif) diinterpretasikan sebagai pemberi dana (bank), yang menyediakan seluruh dana awal bagi pendirian proyek tersebut.

Gambaran di atas, merupakan suatu mekanisme keuangan yang ideal, namun realitasnya kontrak keuangan tersebut tidak banyak menarik bagi para pelaku sistem keuangan syari'ah, seperti bank syari’ah. Dengan kata lain, ada kesenjangan antara teori dengan realitas mekanisme operasi produk yang berbasis profit and loss sharing (PLS) pada lembaga keuangan syari'ah atas produk tersebut. Hal ini tentunya sangat dipengaruhi oleh banyak sebab atau faktor. Faktor ini dapat dikelompokkan menjadi dua, yaitu: faktor internal lembaga keuangan syari'ah (baca: bank syari'ah) dan faktor eksternal lembaga keuangan. Secara internal perbankan syari’ah, mungkin belum dipahami secara baik oleh kalangan internal perbankan mekanisme kerja produk mudharabah; pihak bank bersifat risk-averse atas pembiayaan mudharabah, karena di dalamnya sarat risiko, utamanya risiko yang berkaitan dengan masalah agensi.

Alasan ini dapat muncul karena disebabkan oleh faktor eksternal bank, yaitu kondisi masyarakat pengguna jasa pembiayaan bank syari’ah untuk jenis mudharabah. Yang 
dimaksud kondisi masyarakat adalah keadaan tingkat kejujuran dan keamanahan masyarakat dalam menjalankan produk mudharabah. Sebab pembiayaan mudharabah harus didukung dengan kondisi masyarakat seperti itu. Dengan kata lain, disamping persyaratan teknik administratif, kontrak mudharabah akan berjalan jika terdapat keterbukaan (transparansi).

Kontrak mudharabah adalah kontrak menanggung untung dan rugi antara pemilik dana (bank/principals) dengan nasabah (agents). Pada hubungan kontrak bisnis seperti ini diperlukan saling keterbukaan antara kedua belah pihak (pemilik dana dengan nasabah) dalam hal untung dan rugi bisnis yang dijalankan. Jika salah satu pihak (utamanya nasabah) tidak menyampaikan secara transparan tentang hal-hal yang berhubungan dengan perolehan hasil, sehingga dapat terjadi aktivitas adverse selection dan moral hazard. Dalam transaksi keuangan, masalah adverse selection dan moral hazard merupakan masalah asymmetric information. Kontrak mudharabah adalah kontrak keuangan yang sarat dengan aktivitas asymmetric information.

Asymmetric information merupakan sesuatu yang pasti terjadi dalam kontrak mudharabah. Penyimpangan ini diminimalisasi dalam rangka mengoptimalkan hasil. Hal ini dapat terjadi jika ada penetapan struktur insentif. Presley \& Session (1994) menunjukkan cara-cara untuk mengendalikan asymmetrict information dalam kontrak mudharabah, yang dikenal dengan incentive-compatible constraint ${ }^{1}$. Dengan kata lain, masalah penting yang perlu dicermati dalam kontrak mudharabah adalah memperkecil terjadinya asymmetric information. Asymmetric information ini merupakan bagian dari masalah agensi dalam suatu kontrak keuangan.

\section{Kontrak Mudharabah (Bagi Hasil) dalam Keuangan Syari’ah}

Sebagaimana diuraikan pada bagian sebelumnya, bentuk khusus kontrak keuangan yang telah dikembangkan untuk menggantikan mekanisme bunga dalam transaksi keuangan Islam (syari'ah) adalah mekanisme bagi hasil atau mudharabah (Murinde, Naser dan Wallace, 1995: 210). Mekanisme bagi hasil ini merupakan core product bagi lembaga keuangan syari'ah, seperti bank syari’ah. Sebab bank syari’ah secara eksplisit melarang penerapan tingkat bunga pada semua transaksi keuangannya.

Secara umum prinsip bagi hasil dalam perbankan syari'ah dapat dilakukan dalam empat akad utama, yaitu : Al-Musyarakah; Al-Mudharabah; Al-Muzara'ah; Al-Mushaqah 
(Antonio, 2000). Namun yang banyak dipakai di bank syari'ah adalah al-musyarakah dan al-mudharabah. Kedua akad produk biasanya tergolong sebagai kontrak bagi hasil (Siddiqi, 1983; Chapra, 1985; Warde, 1999; Humayon, Harvey dan Presley, 1999; Antonio, 2000; Muhamad, 2001).

Mudharabah akan berjalan sesuai dengan syari’ah, jika dijalankan sesuai dengan rukun mudharabah. Dengan kata lain, unsur-unsur yang harus ada yang menjadi prasyarat sahnya transaksi mudharabah. Adapun unsur (rukun) perjanjian mudharabah tersebut adalah : (1) Ijab dan Qabul; (2) Adanya Dua Pihak (pihak penyedia dana dan pengusaha); (3) Adanya Modal; (4) Adanya Usaha (al-‘aml), dan (5) Adanya Nisbah (Sadeeq, 2003).

Sebagai suatu kerjasama yang mempertemukan dua pihak yang berbeda dalam proses dan bersatu dalam tujuan, kerjasama ini memerlukan beberapa kesepakatan berupa ketentuan-ketentuan yang meliputi aturan dan wewenang yang dirumuskan oleh kedua belah pihak yang akan menjadi patokan hukum berjalannya kegiatan mudharabah tersebut. Hal-hal yang harus disepakati tersebut antara lain: (1) Manajemen. (2) Tenggang Waktu (Duration); (3) Jaminan (dhiman) (Sadeeq, 2003).

Ketika sebuah kontrak telah disepakati, maka kontrak tersebut menjadi sebuah hukum yang tidak boleh dilanggar oleh kedua belah pihak. Jika ada pelanggaran yang dilakukan oleh salah satu pihak, baik shahib al-mal atau mudharib, maka kontrak menjadi gugur tidak berlaku lagi. Kesepakatan kontrak mudharabah yang menjadi hukum tersebut membawa beberapa implikasi, di antaranya: (1) Mudharib sebagai Amin (orang yang dipercaya); (2) Mudharib sebagai Wakil; dan (3) Mudharib sebagai Mitra dalam Laba (Sadeeq, 2003).

Berdasarkan teori perbankan syari'ah kontemporer, prinsip mudharabah dijadikan sebagai alternatif penerapan sistem bagi hasil. Meskipun demikian, dalam prakteknya, mekanisme bagi hasil dalam memainkan operasional investasi dana bank peranannya sangat lemah. Menurut beberapa pengamat perbankan syari’ah, hal ini terjadi karena beberapa alasan, di antaranya:

(1) Standar Moral; (2) Ketidakefektifan Model Pembiayaan Bagi Hasil; (3) Berkaitan dengan Para Pengusaha; (4) Dari Segi Biaya; (5) Segi Teknis; (6) Kurang Menariknya Sistem Bagi Hasil dalam Aktivitas Bisnis; (7) Permasalahan Efisiensi (Saeed, 2003: 128 - 132).

Kontrak mudharabah merupakan salah satu bagian transaksi keuangan Islam. Dalam kontrak mudharabah (bagi hasil) ini, jika dikaitkan dengan teori keuangan, merupakan kontrak keuangan yang sangat berhubungan dengan masalah agensi yang berbentuk 
asymmetric information. Masalah ini muncul karena, kontrak mudharabah sangat memungkinkan agent (mudharib) melakukan penyimpangan-penyimpangan keuangan hasil proyek yang dijalankan.

\section{Masalah Agensi dalam Kontrak Mudharabah}

Mazhab Syafi'i mendefinisikan mudharabah bahwa pemilik modal menyerahkan sejumlah uang kepada pengusaha untuk dijalankan dalam suatu usaha dagang dengan keuntungan menjadi milik bersama antara keduanya (al-Nawawi, tt: 289). Dalam kontrak seperti ini, ada dua pihak yang saling terikat, yaitu pemilik dana (modal), yang disebut principal dan pemilik keahlian/manajemen, yang disebut sebagai agent. Reichelstein (1992) berpendapat bahwa masalah agensi akan muncul ketika ada seorang prinsipal menyewa seorang agen untuk mengerjakan suatu pekerjaan namun si agen tidak ikut memperoleh bagian dari apa yang dia hasilkan. Sedangkan Stiglitz (1992) mengemukakan bahwa masalah antara prinsipal dan agen akan muncul ketika dalam hubungan antara prinsipal dan agen tersebut terdapat imperfect information.

Berdasarkan dua pendapat di atas, kontrak mudharabah dijalankan oleh bank syari'ah, merupakan suatu kontrak yang mengandung peluang besar terjadinya imperfect information, bila salah satu pihak tidak jujur. Dengan kata lain, model kontrak mudharabah - dimungkinkan - sarat dengan terjadinya imperfect information dalam hubungan antara principal (shahibul mal) dan agent (mudharib), maka muncullah masalah agensi.

Masalah agensi dalam kontrak mudharabah dapat terjadi dalam berbagai bentuk, misalnya: penggunaan biaya proyek yang berlebihan, penahanan keuntungan yang akan dibagikan kepada pemilik modal, dan berbagai kecurangan yang dapat mengurangi laba atau aset perusahaan. Di antara fonomena-fenomena tersebut menurut Arifin (2003) diakui sebagai fenomena yang mendorong munculnya teori agensi.

Istilah masalah principal-agent pertama kali dikemukakan oleh Ross (1973). Masalah ini muncul ketika terdapat asymmetric information baik berkaitan dengan kegiatan maupun informasi yang dimiliki oleh seorang agen. Berangkat dari pandangan awal ini kemudian Jensen (1983) mengelompokkan teori agensi dengan dua pendekatan, yaitu: (1) positive theory of agency dan (2) principal-agent literature. Kedua pendekatan ini sama menelaah kontrak diantara self-interested individual dan sama-sama berpostulat bahwa biaya agensi (agency cost) dapat dimininumkan dengan melalui proses kontrak serta samasama bertujuan mendesain kontrak yang Pareto-efficient (Arifin, 2003: 11). 
Menurut Arifin (2003) kedua pendekatan yang diajukan Jensen memiliki perbedaan, yaitu: (1) Principal-agent literature pada umumnya berorientasi matematis dan non empiris serta berkonsentrasi pada efek dari preferensi dan asymetric information. (2) Positive agency literature pada umumnya berfokus pada uji empiris dan non-matematis serta berkonsentrasi pada efek dari teknologi sistem kontrak dan human atau physical capital yang spesifik.

\section{3.a. Principal-Agent Literature dalam Kontrak Mudharabah}

Pendekatan Principal-Agent Literature yang dikembangkan oleh Ross (1973) melihat bahwa dalam suatu kontrak ternyata timbul masalah hubungan pemilik dengan manajemen (principal-agent problem). Menurut Ross (1973) masalah ini muncul ketika terdapat asymmetric information dari agent terhadap principal. Informasi asimetrik adalah kondisi yang menunjukkan sebagian investor mempunyai informasi dan yang lainnya tidak memilikinya (Jogiyanto, 2000: 369).

Asymmetric information dapat terjadi berupa kegiatan maupun informasi. Masalah yang berkaitan dengan kegiatan dinamakan hidden action, sedangkan masalah yang berkaitan dengan informasi disebut hidden information. Hidden action akan memunculkan moral hazard dan hidden information akan memunculkan adverse selection. Dengan kata lain, Asimetrik informasi merupakan kondisi agent dalam kontrak keuangan biasanya berbentuk moral hazard dan adverse selection. Sadr dan Iqbal mengatakan: adverse selection terjadi pada kontrak utang ketika peminjam memiliki kualitas yang tidak baik atas kredit di luar batas ketentuan tingkat keuntungan tertentu, dan moral hazard terjadi ketika melakukan penyimpangan atau menimbulkan risiko yang lebih besar dalam kontrak (2000, 326).

Dalam kontrak mudharabah, ketika proses produksi dimulai, maka agen menunjukkan etika baiknya atas tindakan yang telah disepakati bersama. Namun setelah berjalan, muncul tindakan yang tidak terkendalikan, yaitu: moral hazard (tindakan yang tidak dapat diamati) dan adverse selection (etika pengusaha yang secara melekat tidak dapat diketahui oleh pemilik modal) (Bashir, 1990: 373). Dari uraian di atas, terlihat bahwa masalah informasi asimetrik adalah sangat berhubungan dengan masalah keuangan atau investasi. Terlebih lagi jika dikaitkan dengan kontrak keuangan mudharabah.

Hubungan antara informasi asimetrik dengan peluang investasi pernah diteliti oleh Ross (1977: 23-40). Kemudian masalah ini dikaji oleh sebagian kalangan dengan berbagai macam pendekatan yang dipilih. Sebagai contoh, Harris dan Raviv (1990: 321-49) menguji 
masalah informasi asimetrik dengan agency model. Penelitian tentang masalah ini, menunjukkan adanya hubungan antara informasi asimetrik dan model agensi dengan batas probabilitas (default probability) peluang investasi. Munculnya asymmetric information ini dapat mempengaruhi besar kecilnya pendapatan investasi yang diperoleh.

Tingkat adverse selection dan moral hazard berhubungan langsung dengan tingkat informasi asimetrik dan ketidak lengkapan pasar. Sehubungan dengan itu, maka bank syari'ah harus memiliki alat screening untuk mengurangi asimetrik informasi yang akan terjadi dalam pembiayaan mudharabah. Agar kontrak mudharabah dapat diminimalkan risikonya dan terjadi hasil maksimal, maka pihak bank syari'ah - sebagai principal - perlu melakukan upaya-upaya pencegahan (adverse selection), misalnya melalui: screening terhadap calon nasabah yang akan dibiayai, screening atas proyek; membuat kontrak yang lengkap (complete contract), misalnya tentang: jangka waktu, nisbah bagi hasil, jaminan. Sementara itu, untuk mencegah terjadinya moral hazard dalam kontrak mudharabah dapat dilakukan monitoring biaya dan proyek.

\section{3.b. Positive Agency Literature dalam Kontrak Mudharabah}

Pada prinsipnya, pengelolaan mudharabah dilakukan oleh mudharib karena kerja tersebut adalah hak sekaligus kewajiban mudharib untuk dapat merealisasikan keuntungan. Dengan demikian tidak boleh dan tidak sah bagi shahibul mal untuk mensyaratkan supaya ia memiliki hak dalam pengelolaan karena bertentangan dengan hak mudharib (ad-Dardiri; Al-Kasani; Asy-Syairazi, dalam Muhammad, 2003: 92). Dengan kata lain, kontrak mudharabah adalah kontrak antara pimilik modal dengan manajemen yang terpisah antara kedua pihak. Hal ini jika dikaitkan dengan pendekatan positive agency-nya Jensen dan Meckling (1976) ada kemiripan. Dalam analisis, Jensen dan Meckling, pendekatan tersebut dimunculkan karena masalah agensi akan muncul dalam perusahaan yang terpisah antara kepemilikan dan manajemennya.

Selanjutnya, Jensen dan Meckling mendefinisikan $\alpha$ (alpha) sebagai bagian saham yang dimiliki oleh manajer. Jika $\alpha=1$ berarti perusahaan dimiliki sepenuhnya oleh manajer dan dia menangung semua risiko jika nilai perusahaan tidak optimal sebagai akibat penggunaan sumber daya perusahaan yang tidak efektif atau bahwa mengarah pada pemborosan (Arifin, 2003: 19). Lebih lanjut Arifin menjelaskan, jika $\alpha<1$, berarti tindakan tidak optimal yang dilakukan manajer ditanggung tidak hanya oleh manajer tetapi juga oleh pemodal luar (outside investors). Setiap rupiah penggunaan dana akan ditanggung oleh 
manajer sebesar $\alpha$ dan oleh investor lain sebesar (1- $\alpha)$. Keadaan ini membuat manajer akan cenderung meningkatkan pengeluaran ‘konsumtif’nya jika $\alpha$ semakin kecil.

Dalam kontrak mudharabah, kepemilikan proyek adalah milik bersama antara pemodal (shahibul mal) dengan pelaksana (mudharib). Namun hak kepemilikannya secara terperinci adalah: modal mudharabah tetap menjadi hak milik shahibul maal, adapun keuntungan yang dihasilkan oleh usaha syarikat mudharabah tadi jadi milik bersama dan pembagian hak kepemilikannya munurut nisbah bagi hasil yang telah disepakati bersama. Jadi, mudharib tidak berhak mengambil bagiannya dari keuntungan tanpa sepengetahuan atau kehadiran shahibul maal dan sebaliknya juga demikian. Keuntungan tersebut jadi milik bersama antara shahibul maal dan mudharib kerena modal dan kerja adalah sejajar, saling berkepentingan dan membutuhkan, maka keduanya harus berhak atas keuntungan dengan nisbah masing-masing (Asy-Syarbini; Al-Bahuti; Ad-Dasuqi; dan Al-Kasani, dalam Muhammad, 2003: 90).

Jika terjadi penyimpangan kontrak, maka shahibul mal dapat menetapkan syarat dan sanksi kepada mudharib. Jika mudharib melanggar ketentuan, maka mudharib harus menanggung akibatnya dan menjamin kerugian yang menimpa modal atau kepentingan shahibul mal. Dalam hal menanggung risiko dan keuntungan atas modal dan proyek, ketentuan fiqh menggariskan sebagai berikut: jika kontrak mudharabah terdapat keuntungan maka pembagian keuntungannya dibagi berdasarkan nisbah yang telah disepakati kedua pihak yang berkontrak (Usmani, 1999: 36). Jika terjadi kerugian, menurut Abu Hanifah dan Ahmad, maka kerugian akan dibagi menurut rasio modal yang disertakan masing-masing pihak yang berkontrak (Usmani, 1999: 37). Dengan demikian, dalam kontrak mudharabah, ternyata mudharib melakukan penyimpangan-penyimpangan yang dilakukan untuk kepentingan dirinya, maka mudharib akan menanggung seluruh kerugian yang diakibatkan penyimpangan yang dilakukan.

Oleh karena itu, shahibul mal harus dapat membuat aturan atau persyaratan yang dapat mengurangi kesempatan mudharib melakukan tindakan yang merugikan shahibul mal. Dalam praktek keuangan modern, Jensen dan Meckling (1976) menawarkan dua cara yang dapat dilakukan pemilik modal untuk mengurangi risiko akibat tindakan manajer yang merugikan, yaitu: pemilik modal melakukan pengawasan (monitoring) dan manajer sendiri melakukan pembatasan atas tindakan-tindakannya (bonding). Implikasi kedua kegiatan ini adalah (1) dapat mengurangi kesempatan penyimpangan manajer sehingga nilai perusahaan (proyek) meningkat, sedangkan (2) keduanya akan memunculkan biaya sehingga akan 
berdampak mengurangi nilai perusahaan (proyek). Jensen dan Meckling (1976) menyatakan bahwa calon investor akan mengurangi munculnya kedua biaya tersebut ditambah dengan kerugian yang masih muncul, meskipun sudah ada monitoring dan bonding, yang disebut residual loss. Antisipasi ketiga biaya yang didefinisikan sebagai biaya agensi ini nampak pada harga saham yang terdiskon saat perusahaan menjual sahamnya.

Dalam kontrak mudharabah, jika hasil proyek selalu berada di bawah harapan maka shahibul mal akan mengakhiri kontrak. Menurut fuqaha dari madzab selain Maliki: mereka berpendapat boleh saja sebagai harga yang lebih rendah dari semestinya, maka jika mudharib melihat bahwa dalam mengelola shahibul maal membahayakan bagi syarikat, ia dapat melarang atau mencegah pengelolanya, jika hal itu terjadi setelah mudharib memulai usahanya. Adapun jika sebelum ia memulai usahanya, maka bagi shahibul maal dapat mengelola modalnya dan mudharib tidak berhak melarangnya dan otomatis batallah akad mudharabah (Ad-Dardiri; Al-Kasani; Asy-Syairazi).

Tindakan-tindakan yang dilakukan shahibul mal (principal's) terhadap mudharib (agent's) ataupun proyek untuk memperkecil masalah agensi, dalam teori keuangan dikenal dengan incentive compatible constraints.

\section{Mekanisme untuk Mengurangi Agensi dalam dalam Kontrak Mudharabah}

Kontrak bagi hasil (mudharabah), jika dihubungkan teori agency, maka ada persamaannya. Sehubungan dengan itu, Khalil, Rickwood dan Muride menjelaskan sebagai berikut :

In an agency theoritical framework, however, the ideal risk - and profit - sharing contract relates to two parties who have identical probability beliefs with respect to the state of nature. One party is the insider (active) who is identified as the agent (entrepreneur); this party has knowledge about a risky profitable investment project which they wish to undertake, but they have zero initial funds to finance it. The outsider (passive) party is interpreted as the principal (bank), who provides the full initial funds needed to establish the project (2000 : 618).

Pihak pengusaha disebut insider, sementara pemberi modal adalah pihak outsider.

Pihak insider diberikan hak aktif atas usaha, dan sebaliknya pihak outsider tidak. Hal ini akan berpengaruh terhadap hak kontrol terhadap aktivitas usaha. Dalam hal ini, lebih lanjut Khalil, Rickwood dan Muride menjelaskan :

The control rights of the project exercised by the agent are the right to make decisions concerning investment and financial reporting, and to know more about the probability distribution of the outcome of the project, given that these outcomes are unobservable by the principal. The bank can be viewed as a passive principal with neither the capability to detect the agent's core attribute (skills, abilities, 
honesty, faithfulness, etc.) costlessly, nor with sufficient power to control the project. In terms of the contract, the bank's utility is represented in money only, whereas there is the inference that the agent's rewards and costs are additively with respect to money and effort. The effort is not costlessly observable by the bank (2000 : 61819).

Hal itu juga yang diargumenkan bahwa kontrak mudharabah menunjukkan suatu kekuatan kontrak untuk memilih (investasi), ketika pada awalnya agen mengontrol proyek dan menikmati hak untuk membuat keputusan berkenaan dengan investasi dan distribusi berdasarkan arus kas. Ini memberikan kebebasan secara penuh kepada pengusaha atas aset, untuk dikelola sendiri tanpa menanggung risiko kerugian yang diakibatkan karena kerugian keuangan.

Namun demikian, secara umum ada beberapa perbedaan antara masalah kontrak mudharabah dengan kontrak agency. Dalam penelitian ini akan diidentifikasi tiga masalah pokok dalam kontrak mudharabah, yaitu : (1) Idiosynchratic uncertainty (risk), (2) Extreme linearity, (3) Discretionary power (Khalil, 2000 : 619).

Dari tiga masalah pokok tersebut dapat dijelaskan sebagai berikut: idiosyncratic uncertainty khususnya terjadi bagi bank. Kontrak bagi hasil adalah kontrak yang tidak bisa dipastikan (uncertainty) pendapatannya. Uncertainty ini bersumber dari beberapa hal, antara lain: return bagi bank diasumsikan tergantung hanya kepada laporan aliran kas masa yang akan datang yang dihasilkan dari beroperasinya kemampuan mendatangkan keuntungan yang pada gilirannya sepenuhnya tergantung kepada keputusan investasi perusahaan yang dibuat oleh agen yang dihadirkan. Lebih jauh agen tersebut tidak diawasi secara penuh, dan memiliki sejumlah kebebasan. Agen tersebut akan berupaya untuk mengeksploitasi situasi ini untuk menggunakan dana secara berlebihan, menghindari resiko dan memperkecil usaha (pekerjaan). Tingkat kerja agen mungkin dianggap tidak dapat diamati (diteliti), dan hal itu tidak dapat dicantumkan dalam kontrak. Stimulus untuk salah merepresentasi hasil mungkin juga muncul dalam situasi ini. Terlebih lagi, uncertainty ini diperburuk oleh kurangnya keamanan atas aset. Secara normal, bank tidak memiliki hak kontrol atas aset-aset yang digunakan dalam proyek kontrak mudharabah, khususnya karena adanya (menurut peraturan Islam) larangan menggunakan aset-aset tersebut. Jika aset ini tidak mudah digunakan secara efektif dan modal tenaga manusia merupakan komponen utama, maka tiadanya jaminan lebih jauh ditekankan. Sebagai tambahan, sistem pelaporan keuangan yang digunakan untuk menilai hasil kontrak utamanya dipilih dan diatur oleh pihak pengusaha. Karenanya uncertainty akan semakin parah dan bank menghadapi kemungkinan resiko yang sangat signifikan khususnya dalam kasus terjadinya kerugian. Hal ini mungkin 
menambah terjadinya masalah agensi berupa “adverse selection dan moral hazard” yang didukung oleh kemampuan pengusaha dalam kontrak semacam itu, untuk menyembunyikan informasi yang berkaitan dengan kemampuan dan latar belakang mereka sebelum berkontrak. Sebagai tambahan, penghasilannya mungkin tidak akan dilaporkan secara jujur oleh agen. Masalah adverse selection ini muncul karena adanya informasi yang asymmetric yang ex-ante antara pihak bank dengan agen, sementara dua masalah moral hazard mungkin merupakan akibat: pertama dari pemilihan usaha oleh pengusaha, dan kedua akibat ketergantungan kepada agen untuk melaporkan informasi pribadi.

Gambaran kedua yang dapat timbul dalam kontrak mudharabah adalah extreme linearity (pembagian yang linear) antara reward dan performance proyek yang diusahakan, reward bagi pihak (agen) adalah berupa fungsi garis lurus hasil yang direalisasikan. Hasil akhir yang mungkin terjadi dan diharapkan lebih tergantung kepada tingkat keterampilan pengusaha dan tingkat usaha yang dilakukan, ditambah dengan menghindari (penggunaan) dana. Hal ini tidak hanya dapat diteliti oleh pihak bank, akan tetapi biayanya pun ditanggung bersama secara proporsional, sementara manfaat yang didapat dari pengecilan (kerja) dan dana hanya dinikmati oleh agen. Hal ini membuat sistem kompensasi pengurus menjadi fungsi cekung yang murni dari hasil yang maksimal (yang menjadikan agen sebagai pemilik klaim atas sisa penghasilan). Dalam beberapa situasi, linearity dapat dianggap, dari sudut pandang kontrak agensi, sebagai satu cara yang efisien untuk menyebarkan resiko yang melekat pada kontrak tersebut. Ia mungkin menyediakan ikatan kepentingan yang sempurna antara bank dengan pengusaha, dan karenanya menyebabkan stimulus yang tepat bagi agen dan aktivitasnya untuk meminimalisir biaya secara efektif dan menyeleksi proyek-proyek investasi. Akan tetapi untuk mencapai hal ini, linearity mensyaratkan monitoring yang efektif dan teknologi verifikasi sehingga konsumsi atas dana dan pengecilan (kerja) dapat di deteksi dan menjadi tanggungan pihak agen. Biaya monitoring mungkin dikenakan pada semua tahap kontrak untuk meyakinkan adanya kepatuhan pada kontrak, dan menyampaikan tanda yang dapat diverifikasi dan informatif mengenai tingkah laku pengusaha. Biaya verifikasi (misalnya biaya auditing) disyaratkan untuk mengecek ketepatan pengukuran performance dan kejujuran laporan penghasilan yang disiapkan oleh sistem keuangan agen.

Penjelasan ketiga bahwa kontrak mudharabah adalah merepresentasi kontrak discretionary power (investasi) karena agen pada awalnya mengontrol proyek dan menikmati hak untuk membuat keputusan berkaitan dengan investasi dan distribusi arus 
kas. Hal ini menimbulkan discretion yang penuh atas aset kepada pengusaha, sama seperti yang dimiliki manajer pada proyeknya sendiri, tanpa menghadapi resiko kerugian secara keuangan. Berbeda dengan modal, didalamnya tidak ada hak otomatis untuk membuat janji kepada dewan direksi dengan menggunakan kekuatan suara yang memungkinkan pemberi dana untuk meneliti usaha yang sedang berjalan. Dalam kondisi ini pengusaha dapat dikarakterisasi sebagai agen yang discretionary, yang menghentikan kepemilikannya atas proyek dalam kaitannya dengan penghasilan, dapat bertindak dalam kepentingannya sendiri. Oleh karena itu kualitas personal (seperti kejujuran, kapabilitas dan lain-lain) dan berbagai karakteristik pengusaha tersebut diharapkan menjadi kriteria vital bagi kontrak semacam ini dalam pengontrolan dan pengurangan masalah-masalah agensi, seperti kebijakan investasi suboptimal dan motivasi untuk lebih mengkonsumsi dana. Refleksi biaya agensi dari gambaran yang penting ini adalah bahwa bank harus menunjukkan isu-isu fundamental mengenai pengusaha ini. Biaya-biaya mungkin dikenakan untuk menilai secara akurat berbagai kualitas yang relevan dari pengusaha yang mungkin berguna dalam pendirian struktur stimulus yang efisien dari pareto optimal kerjasama risk-sharing.

Kontrak bagi hasil - yang dalam Islam disebut mudharabah/ musyarakah merupakan hubungan kontrak antara dua pihak, yang diatur oleh syari'ah, dengan memadukan sumber daya manusia dengan sumber daya modal untuk menghasilkan profit dari proyek yang dijalankan dengan cara bagi hasil sesuai dengan kesepakatan. Dalam kontrak bagi hasil ini ada dua pihak yang saling berhubungan. Pihak pertama financier, yaitu orang yang menyediakan dana yang dibutuhkan untuk menjalankan usaha dengan maksud untuk menghasilkan laba (profit). Pihak kedua adalah usahawan (mudharib) yang memiliki keahlian dan sepenuhnya menjalankan peran usaha. Selanjutnya, usahawan inilah yang melakukan dan pengawasan manajemen usahanya. Pendapatan yang diperoleh dari usaha tersebut dibagi diantara kedua belah pihak sesuai dengan nisbah yang disepakati kedua belah pihak. Sebaliknya, jika usaha mengalami kerugian yang ditimbulkan karena proses normal, maka kerugian ditanggung oleh pemilik modal (shohibul mal).

Dalam kondisi demikian ini, penulis dapat memberikan alasan bahwa pengusaha dapat dicirikan sebagai agent yang bebas dan dapat bertindak dengan sendirinya. Oleh karena itu, kualitas dan karakteristik personal mudharib/pengusaha (agent) diharapkan menjadi kriteria penting untuk kontrak mudharabah. Selain itu juga kriteria proyek yang akan dibiayai. 
Jika karakteristik ini dapat diwujudkan, maka dapat mengurangi timbulnya masalahmasalah agency, sehingga kebijakan investasi mampu memberikan hasil yang optimal. Hubungan masalah agensi dengan karakteristik tersebut dijelaskan sebagai berikut:

\section{a. Karakteristik Proyek dan Masalah Agensi dalam Kontak Mudharabah}

Khalil, Rickwood dan Murinde memberikan pertimbangan kepada bank untuk memasuki kontrak mudharabah dengan mudharib. Bank harus memperhatikan aspek-aspek yang mempengaruhi terjadinya kontrak mudharabah. Proyek yang dapat dipertimbangkan untuk dibiayai dengan mudharabah adalah proyek yang memiliki : profitabilitas proyek baik; variabilitas dan ketidakpastian hasil rendah; risiko kerugian rendah; biaya besar untuk pemantauan usaha rendah; tingkat pengembalian (return) baik; aturan pengawasan ketat; proses akuntansi yang teliti; keadaan sosial dan lingkungan mendukung; jangka waktu kontrak pendek; posisi arus keuangan perusahaan baik; keamanan aset terjamin (2000: 641).

Sementara penelitian Sumiyanto (2004) menyimpulkan bahwa ciri-ciri atau karakteristik proyek yang diperhatikan shahibul mal dalam melakukan kontrak mudharabah meliputi: proyek memiliki risiko kegagalan minimal, menerapkan sistem akuntansi, memberikan return pasti, dan biaya pemantauan kecil (2004: 97).

\section{b. Karakteristik Mudharib/Agent dan Masalah Agensi dalam Kontak Mudharabah}

Proyek mudharabah adalah dijalankan oleh mudharib, ini berarti kedudukan mudharib adalah sebagai manajer proyek tersebut. Dalam hubungan ini Fama (1980) menyatakan bahwa masalah agensi akan sangat berkurang dengan sendirinya, karena manajer akan dicatat kinerjanya oleh pasar manajer baik yang ada dalam perusahaan sendiri maupun yang berasal dari luar perusahaan. Lebih lanjut Fama (dalam Arifin, 2003: 23) menjelaskan, bahwa lapisan manajer atas akan digantikan oleh manajer lapisan di bawahnya jika kinerjanya kurang memuaskan. Persaingan di pasar manajer ini akan memaksa manajer bertindak sebaik mungkin untuk kemajuan perusahaan. Namun mekanisme pasar manajer ini tidak dapat sepenuhnya berjalan karena pasar manajer bukan merupakan pasar yang sempurna.

Sementara dari hasil penelitian yang sama, menunjukkan variabel-variabel penentu untuk menerima atau menolak mudharib untuk kontrak mudharabah adalah, karena: reputasi pengusaha; pengalaman dan kualifikasi pengusaha; ketundukan pengusaha pada ajaran Islam; kesalahan pelaporan hasil yang dilakukan oleh pengusaha; catatan keuangan pengusaha; t dapat meng-akses informasi (Khalil, Rickwood dan Murinde, 2000: 641). 
Senada dengan penelitian Khalil, Richwood dan Murinde, Sumiyanto (2004) menemukan atribut mudharib yang perlu diperhatikan shahibul mal untuk kontrak pembiayaan mudharabah, meliputi: track-record yang baik, pengusaha memiliki keahlian, pengusaha mampu mengoreksi risiko, dan pengusaha memiliki usaha sendiri (2004: 96).

Variabel-variabel di atas merupakan variabel yang secara bertingkat (rangking) dipertimbangkan oleh shahibul mal atas mudharib dalam menjalankan kontrak mudharabah. Dengan demikian, jika shahibul mal memperhatikan variabel-variabel tersebut, maka dapat ditemukan deteksi dini terhadap kontrak mudharabah yang akan dijalankan.

\section{c. Religiusitas Mudharib dan Masalah Agensi dalam Kontak Mudharabah}

Tingkat religiusitas adalah menunjuk pada kondisi keberagamaan seseorang. Dalam kontek ini, religiusitas adalah keadaan di mana seorang shahibul mal atau mudharib memiliki pengetahuan dan menjalankan ketentuan-ketentuan dalam kontrak mudharabah, meninggalkan perilaku riba, dan melakukan pembayaran. Ketentuan ini disyaratkan untuk diikuti, dengan harapan dapat memperkecil masalah-masalah agency. Ketentuan-ketentuan tersebut dimungkinkan dapat membentuk pelaku kontrak mudharabah dapat menjalankannya dengan benar dan dapat mengurangi atau mencegah terjadinya perilaku curang, seperti perilaku tidak jujur atau aktivitas lain yang dalam teori keuangan disebut dengan moral hazard. Dalam hubungan ini, Khalil, Rickwood dan Muride (2000) mengatakan, bahwa :

Placing emphasis on obedience to religious principles attempts to use the voluntary self constrain. It can benefit from informal policing by society at large acting as observers as well as observation by religion officials both informally and formally in the role as members of the shariah board. Evidence of this emphasis provided by contractual provisions may be expected in the face of the significant agency problem (2000 : 622).

Prinsip-prinsip agama dapat digunakan sebagai pengendali diri, agar seseorang tidak berbuat bohong (hazard), tetapi mereka dapat jujur dalam menyampaikan hasil usaha yang diperoleh. Oleh karena itu, di bank syari’ah dibentuk dewan pengawas syari’ah. Dewan ini, yang melakukan tugas berkaitan dengan penegakan prinsip-prinsip syari'ah dalam kontrak keuangan di bank syari’ah. Dengan adanya dewan ini, diharapkan dapat membantu proses pengendalian timbulnya masalah agensi. Dari hasil penelitian Khalil, Rickwood dan Muride menunjukkan bahwa kepatuhan terhadap hukum syari'ah berhubungan dengan variabel 
tidak adanya keterlibatan shahibul mal dalam manajemen, walaupun hubungannya lemah (2000: 633).

\section{d. Incentive Compatible Constraints dan Masalah Agensi dalam Kontak Mudharabah}

Penyimpangan-penyimpangan berupa asymmetric information dalam kontrak mudharabah dapat diminimalisasikan, sehingga dapat mengoptimalkan hasil investasinya. Dalam kaitan ini Presley \& Session menunjukkan cara-cara untuk mengendalikan asimetrik informasi dalam kontrak mudharabah, yang dikenal dengan istilah "incentive-compatible constraint (1994: 584-596).”

Incentive-compatible constraint yang diajukan oleh Presley \& Session mencakup empat aspek, yaitu: (1) modal pengusaha lebih besar dari pada pinjaman atau menggunakan jaminan; (2) melakukan bisnis yang risiko operasinya rendah; (3) melakukan bisnis dengan arus kas yang transparan; dan (4) melakukan bisnis yang biaya tidak terkontrolnya rendah.

Model yang disarankan oleh Presley dan Session tersebut kemudian diadopsi oleh Karim (2000: 579-596) untuk mengendalikan penerapan pembiayaan mudharabah di Bank Muamalat Indonesia. Karim menjelaskan, bahwa: Untuk mengurangi kemungkinan terjadinya risiko asimetrik informasi (moral hazard), maka bank syari'ah (BMI) menerapkan sejumlah batasan-batasan tertentu ketika menyalurkan pembiayaan kepada mudharib, yaitu:

1. Menerapkan batasan agar porsi modal ${ }^{2}$ dari pihak mudharibnya lebih besar dan/atau mengenakan jaminan.

2. Menerapkan syarat agar mudharib melakukan bisnis yang risiko operasinya lebih rendah (Kim dan Sorensen,1986:131-144).

3. Menetapkan syarat agar mudharib melakukan bisnis dengan arus kas yang transparan (Chang,1978:133).

4. Menetapkan syarat agar mudharib melakukan bisnis yang biaya tidak terkontrolnya rendah (Yoon Suh,1988:154-168).

Batasan atau syarat tersebut di atas merupakan bagian dari proses monitoring dan supervisi bank syari'ah atas pembiayaan mudharabah yang disalurkan. Hasil penelitian Sadr dan Iqbal (2000) menyimpulkan, bahwa: dengan meningkatkan pengawasan dan pemantauan, minimalisasi informasi asimetrik dapat memperkecil terjadinya masalah 
agensi. Sementara Ahmed menawarkan tiga cara untuk mengendalikan masalah agensi pada kontrak mudharabah, yaitu: (1) fungsi pengembalian pembiayaan; (2) aturan-aturan auditing; dan (3) fungsi penghargaan atau hukuman (2000: 567-569).

\section{Penutup}

Berdasarkan uraian di atas jelas, bahwa kontrak mudharabah secara langsung memiliki implikasi akan munculnya masalah-masalah agency, yang dapat mempengaruhi struktur pengelolaan kontrak. Ada dua varian ekspektasi yang perlu dipertimbangkan, yaitu: (1) agency contracting cost expectation, dan (2) the governance structure expectation.

Varian yang berkaitan dengan the agency contracting cost expectation menggambarkan tentang keadaan, bahwa kontrak mudharabah sangat rentan menimbulkan masalah agency-contractual dan berhubungan dengan biaya. Dalam hal ini, masalah adverse selection dan moral hazard merupakan hal yang berpengaruh terhadap mekanisme bagi hasil. Teori agency yang baku mengatakan bahwa ada hubungan positif antara tingkat masalah agency dengan besarnya informasi asymetrict dalam kontrak. Dalam hal ini, Muride mengatakan, bahwa "the asymmetrict information is inherent in mudharabah contract” (2000: 621). Dua bentuk informasi asimetri, yaitu: adverse selection dan moral hazard dapat terjadi dalam kontrak mudharabah.

Ada persamaan dan perbedaan antara masalah agensi dalam kontrak keuntungan modern dengan mudharabah. Persamaannya adalah dua cara yang dilakukan pemilik modal (shahibul mal) untuk mengurangi risiko akibat tindakan manajer (mudharib) yang merugikan dapat diterapkan untuk kontrak pembiayaan mudharabah. Hal ini sejalan dengan hadis Nabi, bahwa "Abbas bin Abdul Muthalib jika menyerahkan harta sebagai mudharabah, ia mensyaratkan kepada mudharib-nya agar tidak mengarungi lautan dan tidak menuruni lembah, serta tidak membeli ternak. Jika persyaratan itu dilanggar, ia (mudharib) harus menanggung risikonya. Ketika persyaratan yang ditetapkan Abbas itu didengar Rasulullah, beliau membenarkannya” (HR. Thabrani dari Ibnu Abbas).

Namun ada perbedaan antara keduanya (keuangan modern dengan mudharabah) dalam menentukan masalah agensi. Masalah agensi dalam keuangan modern dihitung berdasarkan selisih antara hasil yang diharapkan (expected return) dengan hasil nyata (actual return). Sementara dalam kontrak mudharabah antara hasil yang diharapkan dengan hasil nyata tidak dapat diselisihkan. Sebab, dalam kontrak mudharabah hasil yang diharapkan tidak dapat dijadikan hasil yang dipastikan di depan. Tindakan memastikan hasil proyek di depan secara pasti adalah termasuk riba. 


\section{Daftar Pustaka}

Al-Jaziri, 1990, Kitab al-Fiqh Ala Madzahib al-Arba’ah, Juz III, Beirut: Dar al-Fikr.

Al-Kasani, 1996, Bada'i' al-Shana'i' fi Tartibi al-Syara'i', Juz. VI, Beirut: Dar al-Fikr.

al-Mishri, Rafiq Yunus, 1991, Al-Jami’ fi Ushul al-Riba, cet.I, Damsyiq: Dar al-Qalam dan Beirut: al-Dar al-Syamiyah.

Al-Omar, Fuad dan Mohammed Abdel-Haq, (1996), Islamic Banking : Theory, Parctice and Challenges, London : Zed Books, p. 43.

Antonio, M. Syafi'i, 2000, Bank Syari'ah : Suatu Pengantar Umum, Edisi Khusus, Jakarta : Tazkia Institute.

Arifin, Zaenal, 2003, "Masalah Agensi dan mekanisme Kontrol pada perusahaan dengan Struktur Kepemilikan Terkonsentrasi yang Dikontrol Keluarga: Bukti dari Perusahaan Publik di Indonesia”, Disertasi, Tidak Dipublikasikan, Jakarta:Program Studi Ilmu Manajemen PPS Faktultas Ekonomi Universitas Indonesia.

Chang, Chun,1987, "Capital Structure as Optimal Contract”, Working Paper, Carlson School of Management, University of Minnesota.

Cho, Y.J. "Inefficiencies From Financial Liberalization in the Absence of Well-Functioning Equity Markets,” Journal of Money, Credit and Banking, No. 18, p. 191-199.

Choudlury, Masuddul Alam,1999, Islamic Venture Capital: A Critical Examination, kumpulam makalah tergabung dalam Third Harvard University Forum on Islamic Finance, (Cambridge: Center for Middle Eastern Studies).

Cobham, David, "Financial International”, Economia, Societa'e Instituzioni; Vol. 5, No. 1, 1993.

Diamond, D.W. "Financial Intermediation and Delegated Monitoring," Review of Economic Studies, Vol 51, pp. 394-414

Harri, Milton and Arthur Raviv, Capital Structure and Informational Role of Debt,” Journal of Finance, vol. 45, pp. 321-49.

Jensen, C. Michael dan W.H. Mechkling, "Theory of the Firm: managerial Behavior, Agency Costs and Ownership Structure”, Journal of Fiancial Economics, No.3, 1976.

Jensen, C. Michael, “Agency Cost of Free Cash Flow, Corporate Finance, and Takeover”, American Economic Review, Vol. 76, No.2, May, 1989

Karim, Adiwarman A., "Incentive Compatible Constrains for Islamic: Banking Some Leassons From Bank Muamalat”, Conference Papers, Fourth International Conference on Islamic Economics and Banking Loughborough University, UK, August 13-15, 2000, pp. 579-598.

Karim, Adiwarman A., “Perbankan Syari’ah : Peluang, Tantangan dan Strategi Pengembangan,” Orientasi, Jurnal Agama, Filsafat dan Sosial, Edisi 3, Tahun III, April 2001, h. 33.

Khalil, Abdel-Fattah A.A., Colin Rickwood, dan Victor Muride, (2000), “Agency Contractual in Profit-Sharing Financing," Islamic Finance : Challenges and Opportunities in The Twenty-First Century, Conference Papers, Fourth International 
Conference on Islamic Economic and Banking Loughborough University, UK, August 13-15, 2000.

Kim, Saeng Wi and Eric Sorensen, "Evidence on the Impact of the Agency Cost of Debt on Corporate Debt Policy”, Journal Financial and Quantitative Analysis, Vol.21, No.2., pp. 131-144.

Muhamad,2002, Manajemen Bank Syari'ah, Yogyakarta: UPP AMP YKPN.

Muhamad,2001, Teknik Perhitungan Bagi Hasil di Bank Syari'ah, Yogyakarta : UII Press.

Muhammad,1998, Lembaga-Lembaga Keuangan Umat (Kontemporer), Yogyakarta: UIIPress.

Muslehuddin, Muhammad, Banking and Islamic Law, ed. II, Pakistan: Islamic Publications, PVT, 1988

Nyazee, Imran Ahsan Khan, 1997,Islamic Law of Business Organisation Partership, Pakistan: Islamic Research Institute Press.

Presley, JR. \& Sessions, JG. "Islamic Economic: The Emergence of a New Paradigm,” The Economic Journal, Vol 104, pp. 584-596

Qudamah, Ibnu, Al-Mughni 'ala al-Syarh al-Kabir, vol. V, Mesir: al-Manar, 1347 H

Reichelstein, Stefan, “Agency”, dalam The New Palgrave Dictionary of Money and Finance, Vol.2, 1992, p. 23-26.

Ross, Stephen, "The Determination of Financial Structure: The Incentive Signalling Approach,” Bell Journal of Economics, Vol. 8, pp. 23-40

Rusyd, Ibnu, Bidayah al-Mujtahid wa Nihayah al-Muqtashid, Semarang: Toha Putera, tt

Sadr, Kazem and Zamir Iqbal, "Choice of Debt or Equity Contract and Asymmetrical Information: An Empirical Evidence," Conference Papers, Fourth International Conference on Islamic Economics and Banking Loughborough University, UK, August 13-15, 2000, pp. 487-499.

Sadr, Kazim, “The Role of Musharakah Financing in the Agricultural Bank of Iran,” Arab Law Quarterly, pp. 245-56.

Saeed, Abdullah,1996, Islamic Banking and Interest, A Study of Prohibition of Riba and Its Contemporary Interpretation, Leiden, New York, Koln: EJ. Brill.

Saleh, Nabil,1988, Financial Transactions and The Islamic Theory of Obligations and Contracs, Chibli Mallat (ed.), Islamic Law and Finance, London: Graham and Trotman, Kluwer Academic Publishers.

Scholtens, Lambertus J.R, "On the Foundations of Financial Intermediation: A Review of the Literatur,” Kredit und Kapital (Germany), Vol. 26, No. 1, 1993, pp. 112-41.

Shiddiqi, Nejatullah, Banking Without Interest, ed. III, (Lahore: Ashfaq Mirza, Managing Director, Islamic Publication Limited), 1980

Siddiqi, M. Nejatullah, “Issues in Islamic Banking, Selected Papers, Virginia : IIIT, 1983

Stiglitz, E. Joseph, "Principal and Agent," dalam The New Palgrave Dictionary of Money and Finance, Vol.2, 1992, p. 185-190.

Suh, Yoon, “Noncontrolable Cost and Optimal Performance Measurement”, Journal of Accounting Research. Vol.26, No. 1, pp.154-168. 
Udovitch, Abraham L., Partnership and Profit in Medival Islam, New Jersey: Princeton University Press, 1970

Warde, Ibrahim, “The Revitalization of Islamic Profit-and-loss Sharing,” Proceeding of the The Harvard University Forum on Islamic Finance, Oktober 1, Cambridge : Harverd Islamic Finance Information Program Centre for Middle Easter Studies, 1999.

Warde, Ibrahim,1999, Islamic Finance in Global Economy, Edinburgh : Edinburgh University Press. 